\title{
Effect of foliar application of calcium chloride on yield and quality of apple varieties
}

Irfanullah Irfan ${ }^{1}$, Muhammad Noman Khan ${ }^{1 *}$, Muhammad Ibrahim ${ }^{2}$, Dawood $^{1}$, Babar Said ${ }^{1}$, Syed Qasim Shah ${ }^{1}$, Farooq ${ }^{2}$ and Asadullah ${ }^{1}$

1. Department of Horticulture, The University of Agriculture Peshawar-Pakistan

2. Agriculture Research Institute Mingora, Swat-Pakistan

*Corresponding author's email: nomanhort@aup.edu.pk

Citation

Irfanullah Irfan, Muhammad Noman Khan, Muhammad Ibrahim, Dawood, Babar Said, Syed Qasim Shah, Farooq and Asadullah. Effect of foliar application of calcium chloride on yield and quality of apple varieties. Pure and Applied Biology. Vol. 9, Issue 2, pp1294-1303. http://dx.doi.org/10.19045/bspab.2020.90134

\begin{tabular}{llll}
\hline Received: 01/11/2019 & Revised: 20/01/2020 & Accepted: 28/01/2020 & Online First: 17/02/2020
\end{tabular}

\section{Abstract}

An experiment "Effect of foliar application of calcium chloride on yield and quality of apple varieties" was carried out in 2016 at Germplasm unit, (fruit) Agricultural Research Institute Mingora, Swat. Germplasm unit (fruit) is situated in Matta valley Biakan Swat at elevation of 1500 meters above sea level. Three levels of $\mathrm{CaCl}_{2}\left(0,0.5\right.$ and $\left.1.0 \mathrm{gL}^{-1}\right)$ were sprayed on four different apple varieties (Smoothee, Royal Gala, Jonagored and Junica). The experiment was laid out as Randomized Complete Block Design with two factors having split plot arrangement with three replications. The data were recorded on fruit drop (\%), fruit diameter $(\mathrm{cm})$, fruit weight $(\mathrm{g})$, yield tree $^{-1}(\mathrm{~kg})$, yield ha ${ }^{-1}(\mathrm{~kg})$, fruit firmness $(\mathrm{kg})$, percent weight loss, starch content, strife index and juice percentage. Results showed that maximum fruit diameter $(6.79 \mathrm{~cm})$, fruit weight $(120.50 \mathrm{~g})$, yield tree ${ }^{-1}(34.50 \mathrm{~kg})$, yield ha ${ }^{-1}(9384.90 \mathrm{~kg})$, fruit firmness $(7.58 \mathrm{~kg})$, starch content $(6.33)$, strife index (0.04) and juice percentage (58.28) was noted in fruits treated with $1.0 \mathrm{gL}^{-1}$ of $\mathrm{CaCl}_{2}$. While the highest fruit drop $(25.88 \%)$ and percent weight loss (7.10) was recorded in control. The results regarding apple varieties indicated that Jonagored had the highest fruit diameter $(7.17 \mathrm{~cm})$, fruit weight $(125.44 \mathrm{~g})$, yield tree ${ }^{-1}(36.13 \mathrm{~kg})$, yield ha ${ }^{-1}(9827.66 \mathrm{~kg})$, strife index $(0.07)$, and juice percentage (57.70), while maximum fruit firmness $(7.51 \mathrm{~kg}$ ), percent weight loss (7.32) was recorded in Junica variety. It can be recommended that $\mathrm{CaCl}_{2} @ 1.0 \mathrm{gL}^{-1}$ and variety Jonagored may be used for good yield and quality under the agro-climatic conditions of Swat.

Keywords: Calcium chloride; Varieties; Yield \& Quality

\section{Introduction}

Apple (Pyrus malus) belongs to the family Roseaceae. Roseaceae family not only contains apple but similarly other fruits as well such as pears, peaches, and plums. Apple production needs long-lasting growing season, adequate sunshine, abundant supply of moisture, protection from mild winter and strong winds. Apples can tolerate pretty low temperatures, but temperatures of $-30{ }^{\circ} \mathrm{C}$ and quick variation in winter from comparatively warm to very cold temperatures are injurious [1].The apple provides good yield in relatively cool, long and slow growing 
period, the type of climate which regularly succeed at 1700-2500 m altitudes. Apple production at low altitudes is limited by it high chilling requirements [2]. Apple trees produce well in a wide range of soil forms. They perform will in a soil with a texture of sandy loam to a sandy clay loam. For successful apple production required decent soil drainage. Close to 6.5 soil $\mathrm{pH}$ is best for apple production [3]. A $100 \mathrm{~g}$ fresh apple holds, water $84.7 \%$, , carbohydrates $13.9 \mathrm{~g}$, proteins $0.4 \mathrm{~g}$, lipids $0.3 \mathrm{~g}$, fiber $0.8 \mathrm{~g}$, ash 0.3 $\mathrm{g}$, vitamin-C $8 \mathrm{mg} / 100 \mathrm{gm}$, sodium $0.3 \mathrm{mg} / 100 \mathrm{~g}$, potassium $145 \mathrm{mg} / 100 \mathrm{~g}$, calcium 7mg/100 g, magnesium 6mg/100 g, iron 480 micro g/100 g, phosphorus $12 \mathrm{mg}$ and iodine 2 micro $g$ (Hussain, 2001). Due to its best nutritive value, in consumption it ranks third position after citrus and banana [1].

According to the Agric. Stat 2014-2015 Apple was produced on an area of 100246 hectares with the production 616748 tons in Pakistan, while in KPK apple was produced on an area of 7921 with the production of 90513 tons. In KPK, apple is cultivated in Swat, Dir, Chitral, Parachinar, Mansehra, North and South Waziristan Agencies. District Swat, with an area of about 4000 square miles with in the Malakand Division, is very significant of all the apple producing districts of Khyber Pakhtunkhwa which is followed by districts of Dir, Mansehra, Chitral and Abbottabad [1].

The improvement and growth of apple tree is affected by water logged soils, shallow soils and soil with hardpan [4].

Several cultivars of apples being grown in Pakistan which includes Top Red, Red Spur, Apple Elite, Oregon Spur, Red Rom Beauty, Red Delicious, Golden Delicious, Super Gold, Red Chief, Royal Gala, Mondial Gala, Spartan And Double Red [4].

Pre- and post-harvest calcium applications have been used to delay aging or ripening, to reduce post-harvest deterioration, and to control the development of many physiological disorders in vegetables and fruits [5]. $\mathrm{Ca}^{2+}$ ions raises the cohesion of cell-walls [6]. It is also involved in decreasing the rate of ripening and senescence [7]. Pre and postharvest application of calcium may delay senescence in fruits with no harmful effect on customer [8]. Application of calcium stabilizes the plant cell wall and protects it from cell wall degrading enzymes [9]. Level of senescence often depend on the calcium position of the tissue and by increasing calcium levels, various parameters of senescence such as respiration, protein, chlorophyll content and membrane variability are changed [10]. Variance in growing situation, environmental factors, and fruit development can affect the amount of calcium uptake by fruits $[5,11]$. Foliar sprays should be done at late fruit growth stages [11]. At least three sprays applied at monthly intervals started from May or June is usually vital [12]. Foliar spray of calcium throughout the fruit growth period significantly increases the value of produce, [13]. Keeping in view the importance of calcium, the present experiment was conducted to examine the effect of foliar application of calcium chloride on the growth, yield and quality of apple varieties with the following objectives: To find out optimum dose of calcium chloride for high yield, fruit quality and production of apple. To explore better yielding and quality apple variety for the Agro climatic condition of Swat valley. To find out the interactive effect of $\mathrm{CaCl}_{2}$ and varieties on yield and quality of apple.

\section{Materials and methods}

A research study on the "Effect of foliar application of calcium chloride on yield and quality of apple varieties" was carried out during 2016 at Germplasm unit, (Fruits) Agricultural Research Institute Mingora, Swat. Germplasm unit, (Fruit) is situated in Matta valley Biakan Swat at elevation of 
1500 meters above sea level. Varieties selected for experiment were Smoothee, Royal Gala, Jonagored and Junica. Calcium chloride was spray in three concentrations $\left(0 \mathrm{~g} \mathrm{~L}^{-1}, 0.5 \mathrm{~g} \mathrm{~L}^{-1}, 1 \mathrm{~g} \mathrm{~L}^{-1}\right)$. The research was laid out in two factors Randomized complete block design (RCBD) with split plot arrangement replicated three times. Varieties were assigned to main plot and $\mathrm{CaCl}_{2}$ was considered as sub-plot. The selected trees were of uniform size and age (16 year old) (Table 1).

\section{Application of calcium chloride}

Foliar application of calcium chloride were applied at 15 days interval. Spray was applied on the following dates. To avoid phyto toxicity the spray application was carried out in the late afternoon.
1. $\mathrm{T}_{1}: 1^{\text {st }}$ June
2. $\mathrm{T}_{2}: 15^{\text {th }}$ June
3. $\mathrm{T}_{3}: 1^{\text {st }}$ July
4. $\mathrm{T}_{4}: 15^{\text {th }}$ July

Table 1. Shows factors

\begin{tabular}{|c|c|}
\hline Factor "A" Varieties (Main plot) & Factor "B" Calcium chloride (Sub-plot) \\
\hline V1: Smoothee & $\mathrm{C}_{1}=0 \mathrm{gL}^{-1}$ \\
\hline V2: Royal Gala & $\mathrm{C}_{2}=0.5 \mathrm{gL}^{-1}$ \\
\hline V3: Jonagored & $\mathrm{C}_{3}=1.0 \mathrm{gL}^{-1}$ \\
\hline V4: Junica & \\
\hline
\end{tabular}

\section{Management practices}

Two parts SSP and one part potassium chloride fertilizers were mixed together and then $2 \mathrm{~kg}$ mixture were applied to each tree. Well rotten FYM was also applied at the rate of half wheel barrow tree ${ }^{-1}$. The normal pest and diseases control measures; weeding and irrigation were also practiced as per need.

\section{Parameters studied}

Following parameters were studied during the research.

\section{Fruit drop (\%)}

Number of fruit drop was counted and weighed on daily basis in each treatment of each replication. The total weight of dropped fruits till the harvest was calculated and its percentage was calculated with the following formula.

Fruit drop $(\%)=$ Fruit drop tree ${ }^{-1} \mathrm{~kg} /$ yield tree $^{-1} \mathrm{~kg}$ x 100

\section{Fruit diameter $(\mathbf{c m})$}

The Vernier caliper was used to determine the fruit diameter of randomly selected five fruits from every treatment in each replication and then average was calculated.

\section{Fruit weight (g)}

Five fruits were randomly selected for every replication in each treatment and weighted with the help of simple balance and then average was computed.

Yield tree $^{-1}(\mathbf{k g})$

Yield tree ${ }^{-1}$ was determined by measuring the weight of all fruits from the tree with the help of simple balance.

Yield ha-1 (kg)

Data was collected from three trees per treatment. The following formula was used to determined yield ha ${ }^{-1}$.

Yield ha ${ }^{-1}=$ No. of trees $\mathrm{ha}^{-1} \mathrm{x}$ Yield tree ${ }^{1}(\mathrm{~kg})$

\section{Fruit firmness ( $\mathrm{kg}$ )}

The firmness of peeled fruit was calculated on both sides of each apple with effegi, Italian (1978) penetrometer, fitted with 1 diameter probe.

\section{Percent weight loss}

Percent weight loss was determined randomly from each sample in each replication of every treatment was use. The same sample was evaluated for weight loss each time at weekly gap until the end of 
experiment. The Percent weight loss was calculated by the following formula.

Weight loss $(\%)=\underline{\text { Fruit weight }- \text { Weight after week }} \times 100$ Fruit weight

\section{Starch content}

Starch content was determined by recommended method of [14].

Preparation of Iodine solution

$8.8 \mathrm{gm}$ of potassium iodide was weighted and dissolved in $30 \mathrm{ml}$ warm water, then $2.2 \mathrm{gm}$ of Iodine crystal was added to the mixture and shaken until the crystal was thoroughly dissolved. The mixture was diluted with distilled water up to 1 liter. The solution was kept in the dark colored bottle.

\section{Testing the fruit sample}

12 fruits samples were taken from apple tree (6 from lateral side and 6 from central side). Each apple was cut in half across the core and immersed the exposed surface to the iodine solution. The starch react with iodine solution and produced a blue-black colour. Where there was no reaction, no colour change.

\section{Evaluating the results}

The colour intensity was compared with a pictorial chart to estimate the internal fruit maturity. Each fruit was rated (1-9 score) by a visual comparison with pictorial chart and the number was recorded by corresponding pattern. The procedure was repeated for all 10 fruit samples. An average rating of all the fruit was calculated to determine the fruit maturity.

\section{Strife Index}

The strife index is maturity index which was determined by the following formula;

\section{Strife index $=\quad \underline{\text { Fruit firmness }}$ Brix $20^{\circ} \mathrm{C}$ starch iodine index}

\section{Juice percentage}

Juice percentage was determined by extracting juice from a unit weight of apple sample. The juice \% was calculated by the following formula;

Juice percentage $=$ juice weight + beaker - beaker weight $\times 100$ Weight of apples

\section{Statistical procedure}

Statistical analysis was approved out through software Statistix 8.1 at $5 \%$ level of significance [15].

\section{Results and discussion}

The effect of foliar application of calcium chloride at different levels was examined for fruit drop, fruit weight, fruit diameter, yield tree $^{-1}$, yield $\mathrm{ha}^{-1}$, firmness of fruit, percent weight loss, starch content, strife index and juice percentage. Calcium chloride concentration was $0 \mathrm{~g} \mathrm{~L}^{-1}, 0.5 \mathrm{gL}^{-1}$ and 1.0 $\mathrm{gL}^{-1}$. Data collected for all the yield and quality factors are discussed as follows.

\section{Fruit drop (\%)}

The data regarding fruit drop are presented in (Table 2). The analysis of the variance showed that fruit drop (\%) was positively affected by calcium chloride concentration and varieties, while their interaction was found not significant.

The mean values of the data presented that maximum fruit drop $(25.88 \%)$ was noted in those treatments in where no spray was done, followed by $(17.03 \%)$ noted in those treatments which were treated with $0.5 \mathrm{~g} \mathrm{~L}^{-1}$ where least fruit drop (11.39\%) was noted in treatments which were treated with $1 \mathrm{~g} \mathrm{~L}^{-1}$ of $\mathrm{CaCl}_{2}$.

In case of varieties the maximum fruit drop (24.25\%) was noted in Smoothee variety, followed by (20.67\%), (16.68 \%) in Royal Gala and Junica varieties respectively. While the minimum fruit drop $(10.81 \%)$ was noted in Jonagored variety.

Decrease in fruit drop may be due to the lignin and cellulose formation these materials are required for building plant structure and prevent abscission layer formation hence, pre harvest fruit drop was significantly reduce. Calcium improved fruit set and thus fruit drop decreases [16]. Same result was found by [17] who reported that the calcium application decreases fruit drop. While in case of varieties decrease in fruit drop may be due to its genetic makeup. Same result was 
found by [18] who reported that minimum fruit drop were noted in Tex. A. 69 peach variety.

\section{Fruit Diameter (cm)}

The data regard to the fruit diameter $(\mathrm{cm})$ are given in the (Table 2), The analysis of the variance showed that fruit diameter $(\mathrm{cm})$ was significantly affected by $\mathrm{CaCl}_{2}$ levels, apple varieties and their interaction.

The mean values for $\mathrm{CaCl}_{2}$ showed that the maximum fruit diameter $(6.79 \mathrm{~cm})$ was noted in fruits sprayed with $1 \mathrm{~g} \mathrm{~L}^{-1} \mathrm{CaCl}_{-2}$ followed by $(5.87 \mathrm{~cm})$ recorded in fruits treated with $0.5 \mathrm{gL}^{-1}$ of $\mathrm{CaCl}_{-2}$. While the lowest fruit diameter $(5.58 \mathrm{~cm})$ was observed in fruit where no spray was done.

The data regarding varieties results showed that maximum fruit diameter $(7.17 \mathrm{~cm})$ was noted in Jonagored, followed by $(6.30 \mathrm{~cm})$, $(5.37 \mathrm{~cm})$ in Junica and Royal Gala varieties respectively, while the minimum fruit diameter $(5.13 \mathrm{~cm})$ was noted in Smoothee variety.

The interaction between $\mathrm{CaCl}_{2}$ and varieties showed that the maximum fruit diameter $(8.79 \mathrm{~cm})$ was noted in fruits of Jonagored variety sprayed with $1 \mathrm{gL}^{-1} \mathrm{CaCl}_{-2}$, while the minimum fruit diameter $(4.49 \mathrm{~cm})$ was noted in fruits of Smoothee variety sprayed with 0.5 $\mathrm{gL}^{-1}$ of $\mathrm{CaCl}_{-2}$.

Improvement in fruit diameter may be due to the cell division and elongation. Foliar application of calcium improve fruit diameter because it speed up the carbon dioxide intake and ammonium absorption [19]. Calcium application increases fruit diameter because it help in cell division and cell elongation [20]. In case of varieties increase in fruit diameter may be due to its genetic makeup. Same result was found by [21]. Who reported that maximum fruit diameter was noted in Jonathan variety.

\section{Fruit weight (g)}

Data pertaining weight of fruit is showed in (Table 2). The mean table showed that fruit weight was significantly influenced by different levels of calcium chloride and varieties, while their interaction was found not significant.

The mean values indicate that fruit weight was significantly improved with foliar application of calcium as compared to untreated fruit. The maximum fruit weight $(120.50 \mathrm{~g})$ was noted in the plant treated with $1 \mathrm{gL}^{-1}$ calcium chloride, followed by $(114.25$

g) which was noted in fruits treated with 0.5 $\mathrm{gL}^{-1}$ calcium chloride, while the minimum fruit weight (108.33 g) was recorded in fruit where no spray was done.

Among the varieties the highest fruit weight (125.44 g) was noted in Jonagored followed by (117.22 g), (110.44 g) in Royal Gala and Junica varieties respectively. The lowest fruit weight $(104.33 \mathrm{~g})$ was noted in Smoothee variety.

Increase in fruit weight may be due to the ammonium absorption ammonium help in photosynthates production. Calcium levels increase the rate of photosynthesis as it help in ammonium absorption [19]. These result are in line with the results of [22] who stated that foliar spray of calcium significantly increased fruit weight in date palm. In case of varieties increase in fruit weight may be due to its genetic makeup. Same results were found by [23], who reported maximum fruit weight was noted in early grand peach variety.

\section{Yield tree-1 (kg)}

The data pertaining yield per tree is displayed in (Table 2), mean table data revealed that foliar application of calcium and varieties significantly affected yield per tree while the interactive effect was non-significant.

The mean values for calcium chloride indicated that the maximum yield tree ${ }^{-1}$ $(34.50 \mathrm{~kg})$ was noted in fruit trees sprayed with $1 \mathrm{gL}^{-1}$ of calcium chloride, followed by $(28.36 \mathrm{~kg})$ was noted in fruit trees sprayed with $0.5 \mathrm{gL}^{-1}$ of calcium chloride. While the minimum yield tree ${ }^{-1}(21.26 \mathrm{~kg})$ was noted in trees where no spray was done. 
Mean values for varieties indicated that the maximum yield tree ${ }^{-1}(36.13 \mathrm{~kg})$ noted in Jonagored, followed by $(30.89 \mathrm{~kg}),(24.82$ $\mathrm{kg}$ ) in Junica and Royal Gala varieties respectively. While the minimum yield tree ${ }^{-1}$ (20.33 kg) was observed in Smoothee variety.

Increase in yield tree ${ }^{-1}$ may be due to the fruit diameter and fruit weight. Calcium helps in proper cell division, cell elongation, cell functioning, and resistance to toxin as a result in increase in fruit diameter and fruit weight [20]. The results are in agreement with the results of [23] who observed that foliar application of calcium increased yield per tree.In case of varieties increase in yield tree

${ }^{1}$ may be due to its genetic makeup. Same result was found by [17] who reported that maximum yield tree ${ }^{-1}$ was noted in Anna apple variety.

Yield ha-1 $\mathbf{( k g})$

The data pertaining yield per ha is showed in (Table 2), the mean table data revealed that foliar application of calcium and varieties significantly influenced yield per ha, while the interactive effect was non-significant.

The mean data showed that the maximum yield ha-1 $(9384.90 \mathrm{~kg})$ was noted in the fruit treated with $1 \mathrm{gL}^{-1}$ of calcium chloride, followed by $(7716.18 \mathrm{~kg})$ which was treated with $0.5 \mathrm{gL}^{-1}$ of $\mathrm{CaCl}_{2}$, while the minimum yield $\mathrm{ha}^{-1}(5782.27 \mathrm{~kg})$ was noted in treatments where no spray was done.

Between the varieties the maximum yield ha ${ }^{1}$ (9827.66 kg) was recorded in Jonagored, followed by $(8401.78 \mathrm{~kg}),(6750.74 \mathrm{~kg})$ in Junica and Royal Gala varieties respectively. The minimum yield $\mathrm{ha}^{-1}(5530.97 \mathrm{~kg})$ was noted in Smoothee variety.

Increase in yield ha ${ }^{-1}$ may be due to increase in fruit weight and diameter. Application of calcium effects in high $\mathrm{Co}_{2}$ intake and strong ammonium absorption produced more production of photosynthates thus effects in maximum yield [19]. The results are agreement with [24] who noted an increased yield $\mathrm{ha}^{-1}$ in peach when calcium was applied. While in case of varieties increase in yield $\mathrm{ha}^{-1}$ may be due to its genetic makeup. Same results were found by [25], who reported that maximum yield $\mathrm{ha}^{-1}$ was noted in Roma tomato cultivar.

\section{Fruit firmness (kg)}

The data presented in (Table 2) shows firmness of fruit. The statistical analysis of data displays that firmness $(\mathrm{kg})$ of apple fruit was significantly affected by calcium chloride application and varieties, while their interaction was found not significant.

The mean values showed that fruits treated with $1 \mathrm{gL}^{-1}$ calcium chloride gave the highest fruit firmness $(7.58 \mathrm{~kg})$, followed by $(7.12$ $\mathrm{kg}$ ) which was noted in those fruits which were treated with $0.5 \mathrm{gL}^{-1}$ of $\mathrm{CaCl}_{2}$, while the lowest firmness $(6.23 \mathrm{~kg})$ was found in fruits where no spray was done.

Among the varieties the high fruit firmness (7.51 kg) was found in junica, followed by $(7.06 \mathrm{~kg}),(6.78 \mathrm{~kg})$ which was noted in Royal Gala and Smoothee varieties respectively. While low fruit firmness $(6.57 \mathrm{~kg})$ was noted in Jonagored variety.

Fruit firmness depend on the increase of rigidity. This rigidity is due to the presence of Calcium which is present in the cell wall and cell membrane [20]. The strength of cell wall and cell membrane is due to the cross arrangement of $\mathrm{CaCl}_{2}$ like a bridge which give support to it. $\mathrm{CaCl}_{2}$ increase the rigidity, softening, and also decrease cell deterioration [26] and [27]. Same results were found by [23]. In case varieties in fruits firmness may be due to genetic structure or genetic makeup. Same results were found with [28] who reported that maximum fruit firmness was noted in Anna apple variety.

\section{Percent weight loss}

Data presented in (Table 2) shows percent weight loss. The statistical analysis of data presented that percent weight loss of apple was significantly affected by calcium 
chloride and varieties while their interaction was found not significant.

The mean values shows that maximum percent weight loss $(7.10 \%)$ occurred in those fruits in which no spray was done, followed by $(6.25 \%)$ which were treated with $0.5 \mathrm{gL}^{-1}$ of $\mathrm{CaCl}_{2}$, while minimum percent weight loss $(5.29 \%)$ was noted in those fruits which were treated with $1 \mathrm{gL}^{-1}$ of calcium chloride.

Among the varieties the maximum percent weight loss $(7.32 \%)$ was recorded in Junica, followed by $(6.73 \%),(5.88 \%)$ were noted in Smoothee and Royal Gala varieties respectively, while minimum percent weight loss $(4.93 \%)$ was noted in Jonagored variety. Decrease in weight loss may be due to the structure of the skin and nature of waxes on the surface of the fruit. The minimum present weight loss may be due to ideal level of $\mathrm{CaCl}_{2}$ which worked as semi permeable membrane and cell wall is integrated which slow down the evapo-transpiration and level of respiration in fruits. Therefore, the $\mathrm{CaCl}_{2}$ solution at optimum level reduces the present weight loss in fruits [29]. Current results are in agreement with [30] that high weight loss has been examined in control plot fruits. Same result was examined by [31] who observed that the increase in weight loss in apple fruits was recorded in untreated fruits. While in case of varieties decrease in present weight loss may be due to its genetic makeup. The similar effects were observed by [32]. Who stated that maximum weight loss was noted in golden delicious variety.

\section{Starch content}

Data on starch content is presented in (Table 2 ), the statistical analysis of data showed that starch content was influenced significantly by calcium chloride levels while varieties and their interaction was found not significant. The mean table revealed that starch content was significantly improved with calcium treatment as compared to untreated fruits. The highest starch content (6.33) was noted in fruits treated with $1 \mathrm{gL}^{-1}$ of calcium chloride, followed by (5.50) was recorded in those fruits which were treated with $0.5 \mathrm{gL}^{-1}$ of calcium chloride. The lowest starch content (3.33) was observed in those fruits in which no spray was done.

Increase in starch iodine score may be due to the exchange of starch to sugar. Calcium converted starch into sugar at the onset of ripening to meet the respiratory demand of the fruit [33]. Same result was observed by [21]. Who reported that calcium application delay the ripening process of fruit, therefore the conversion of starch to sugar is also less with $\mathrm{CaCl}_{2}$ application.

\section{Strife index}

The data regarding strife index are given in (Table 2), the analysis of the variance showed that strife index was significantly influenced by $\mathrm{CaCl}_{2}$, varieties and their interaction.

The mean values for $\mathrm{CaCl}_{2}$ indicated that maximum strife index (0.04) was noted in fruits sprayed with $1 \mathrm{gL}^{-1}$ of $\mathrm{CaCl}_{2}$, followed by $(0.03)$ recorded in fruits sprayed with 0.5 $\mathrm{gL}^{-1}$ of calcium chloride. While the minimum strife index (0.02) was noted in fruits where no spray was done.

Among the varieties variation showed that the high strief index (0.05) was noted in Jonagored, followed by $(0.03),(0.02)$ were noted in Junica and Royal Gala varieties respectively, while the low strife index (0.01) was observed in Smoothee variety.

The interaction between $\mathrm{CaCl}_{2}$ and varieties showed that the highest strife index (0.08) recorded in Jonagold variety at $1 \mathrm{gL}^{-1}$ of $\mathrm{CaCl}_{2}$, while the minimum strife index (0.01) was noted in Smoothee variety where no spray was done. [34] recommended that the index value should be between 0.069-0.072.

\section{Juice percentage}

The data about juice percentage is displayed in (Table 2), the analysis of variance presented that juice percentage was significantly affected by $\mathrm{CaCl}_{2}$ and apple 
varieties while their interaction was found not significant.

The mean value for $\mathrm{CaCl}_{2}$ shows that the maximum juice percentage $(58.28 \%)$ was noted in fruits sprayed with $1 \mathrm{gL}^{-1}$ of $\mathrm{CaCl}_{2}$, followed by $(55.17 \%)$ was noted in fruits sprayed with $0.5 \mathrm{gL}^{-1}$, whereas the minimum juice percentage $(51.95 \%)$ was noted in those fruits in which no spray was done.

Mean values for varieties showed that maximum juice percentage $(57.70 \%)$ was noted in Jonagored, followed by (55.23 \%), ( $55.15 \%$ ) were noted in Royal Gala and Junica varieties individually which was statistically similar, while the minimum juice while the minimum juice percentage $(52.45$
$\%)$ was noted in Smoothee variety. Increase in juice percentage may be due to water content of the fruit and low water loss. The loss in water decrease the juice content of apple fruit as juice content of apple fruit depends on the water content of the fruit [35, 36]. The results were same with [37] who observed that the juice content was significantly high with high $\mathrm{CaCl}_{2}$ concentration as compared to control. While in case of varieties increase in juice percentage may be due to its genetic makeup. Same result was found by [37], who reported that high juice percentage was noted in Royal Gala variety.

Table 2. Fruit drop (\%), fruit diameter $(\mathrm{cm})$, fruit weight $(\mathrm{g})$, yield of tree $(\mathrm{kg})$, yield per hectare, fruit firmness (kg), percent weight loss, starch content, strife index, and juice percentage

\begin{tabular}{|c|c|c|c|c|c|c|c|c|c|c|}
\hline $\begin{array}{c}\text { Factors: } \\
\text { Level: }\end{array}$ & $\begin{array}{c}\text { Fruit } \\
\operatorname{drop}(\%)\end{array}$ & $\begin{array}{c}\text { Fruit } \\
\text { diameter } \\
(\mathrm{cm})\end{array}$ & $\begin{array}{c}\text { Fruit } \\
\text { Weight } \\
\text { (g) }\end{array}$ & $\begin{array}{c}\text { Yield of } \\
\text { Tree } \\
(\mathrm{kg})\end{array}$ & $\begin{array}{l}\text { Yield per } \\
\text { hectare }\end{array}$ & $\begin{array}{c}\text { Fruit } \\
\text { Firmness } \\
(\mathbf{k g})\end{array}$ & $\begin{array}{c}\text { Percent } \\
\text { weight } \\
\text { loss } \\
\end{array}$ & $\begin{array}{l}\text { Starch } \\
\text { content }\end{array}$ & $\begin{array}{l}\text { Strife } \\
\text { Index }\end{array}$ & Juice $\%$ \\
\hline \multicolumn{11}{|c|}{ Factor A - Varieties (Mainplot) } \\
\hline Smoothee & $24.25 \mathrm{a}$ & $5.13 \mathrm{a}$ & $104.33 d$ & $20.33 d$ & $5530.97 \mathrm{~d}$ & $6.78 \mathrm{~d}$ & $6.73 c$ & $5.11 \mathrm{~b}$ & $0.01 \mathrm{~d}$ & $52.45 \mathrm{c}$ \\
\hline Royal gala & $20.67 \mathrm{~b}$ & $5.73 b$ & $117.22 \mathrm{c}$ & $24.82 b$ & $6750.74 \mathrm{c}$ & $7.06 \mathrm{c}$ & $5.88 \mathrm{~b}$ & $5.00 \mathrm{c}$ & $0.02 \mathrm{c}$ & $55.23 \mathrm{~b}$ \\
\hline Jonagored & $10.81 \mathrm{~d}$ & $7.17 \mathrm{~d}$ & $125.44 \mathrm{a}$ & $36.13 \mathrm{a}$ & $9827.66 \mathrm{a}$ & $6.57 \mathrm{a}$ & $4.93 \mathrm{~d}$ & $4.89 \mathrm{~d}$ & $0.05 \mathrm{a}$ & $57.70 \mathrm{a}$ \\
\hline Junica & $16.68 \mathrm{c}$ & $6.30 \mathrm{c}$ & $110.44 \mathrm{~b}$ & $30.89 \mathrm{c}$ & $8401.78 b$ & $7.51 \mathrm{~b}$ & $7.32 \mathrm{a}$ & $5.22 \mathrm{a}$ & $0.03 \mathrm{~b}$ & $55.15 b$ \\
\hline \multicolumn{11}{|c|}{ Factor B - Calcium chloride (sub-plot) } \\
\hline $\mathbf{0}$ & 25.88 a & $5.58 \mathrm{a}$ & $108.33 \mathrm{c}$ & $21.26 \mathrm{c}$ & $5782.27 \mathrm{c}$ & $6.23 \mathrm{c}$ & $7.10 \mathrm{c}$ & $3.33 \mathrm{a}$ & $0.02 \mathrm{c}$ & $51.95 \mathrm{c}$ \\
\hline 0.5 & $17.03 \mathrm{~b}$ & $5.87 \mathrm{~b}$ & $114.25 b$ & $28.36 \mathrm{~b}$ & $7716.18 b$ & $7.12 b$ & $6.25 \mathrm{~b}$ & $5.50 \mathrm{~b}$ & $0.03 \mathrm{~b}$ & $55.17 \mathrm{~b}$ \\
\hline 1.0 & $11.39 \mathrm{c}$ & $6.79 \mathrm{c}$ & $120.05 \mathrm{a}$ & $34.50 \mathrm{a}$ & $9384.90 \mathrm{a}$ & $7.58 \mathrm{a}$ & $5.29 \mathrm{a}$ & $6.33 c$ & $0.04 \mathrm{a}$ & $58.28 \mathrm{a}$ \\
\hline & & & 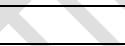 & & & & & & & \\
\hline
\end{tabular}

\section{Conclusion and recommendations}

On the basis of obtained results the following conclusion are made. The fruits of apple trees sprayed with $1 \mathrm{gL}^{-1}$ of $\mathrm{CaCl}_{-2}$ showed highest fruit diameter $(\mathrm{cm})$, weight of fruit $(\mathrm{g})$, yield tree ${ }^{-1}(\mathrm{~kg})$, yield ha ${ }^{-1}(\mathrm{~kg})$, firmness of fruit $(\mathrm{kg})$, starch content, strife index, juice percentage with the minimum fruit drop (\%) and percent weight loss. The fruits of apple variety Jonagored showed maximum fruit diameter $(\mathrm{cm})$, fruit weight $(\mathrm{g})$, yield tree ${ }^{-1}(\mathrm{~kg})$, yield ha ${ }^{-1}(\mathrm{~kg})$, strife index, juice percentage with the minimum fruit firmness $(\mathrm{kg})$, percent weight loss, fruit drop (\%).The fruits of apple variety Junica showed highest fruit firmness $(\mathrm{kg})$, percent weight loss with the minimum fruit diameter $(\mathrm{cm})$, fruit weight $(\mathrm{g})$, yield tree ${ }^{-1}(\mathrm{~kg})$, yield $\mathrm{ha}^{-1}$, juice percentage. It can be recommended that $\mathrm{CaCl}_{2} @ 1 \mathrm{gL}^{-1}$ should be used for better yield and quality of apple. Among the tested varieties Jonagored showed best result in majority parameters and hence may be grown for better yield and quality under the agro-climatic conditions of swat. 


\section{Authors' contributions}

Conceived and designed the experiments: I Irfan \& MN Khan Performed the experiments: I Irfan, MN Khan \& M Ibrahim, Analyzed the data: I Irfan, SQ Shah, \& Dawood Contributed materials/ analysis/ tools: Farooq, Asadullah \& B Said Wrote the paper: I Irfan \& MN Khan.

\section{References}

1. Bokhari SAA (2002). The sweet gold of Pakistan. Export promotion Bureau of Pakistan.

2. Janick J (1974). The apple in Java. Hort Sci 9(1): 13-15.

3. Gao $G$ (2001). Growing apples in the home orchard. Ohio State University Fact Sheet http: // Ohioline Ag Ohio- state Edu/ lines/ fruit Html.

4. Chaudhary MI (1994). Fruit crops in horticulture. M. N. Malik. (Editor) Ist Edn. National Book Foundation, Islamabad, Pakistan, pp 471-473.

5. Conway WS, Sams CE, Wang CY \& Abbott JA (1994). Additive effect of postharvest calcium and heat treatment on reducing decay and maintaining quality in apple, J Am Soc Hortic Sci 119: 49-53.

6. Demarty $\mathrm{M}$, Morvan $\mathrm{C} \&$ Thellier $\mathrm{M}$ (1984). Ca and the cell wall. Plant cell Environ 7: 441-448.

7. Ferguson IB (1984). Calcium in plant senescence and fruit ripening. Plant cell Environ 7: 477-489.

8. Lester GE \& Grusak MA (2004). Field application of chelated calcium: postharvest effect on cantaloupe and honey dew fruit quality. Hort Technol 14:29-38.

9. White PJ \& Broadley MR (2003). Calcium in plants. Ann Bot 92: 487-511.

10. Pooviah BW (1986). Roleof calcium in prolonging storage life of fruit and vegetable. Food Tech 40: 86-89.

11. Wojcik P \& Swiechowsk (1999). Effect of calcium chloride sprays at different water volume on "szampion" apple calcium concentration. $J$ of Plant Nutr 24(24 (4\&5): 639-650.
12. Cparile J (2001). Maximizing calcium uptake in apple, University of California small farm center report.

13. Subbiah K \& Perumal R (1990). Effect of calcium sources, concentration, stages and number of sprays on physic-chemical properties of tomato fruits, South Indian Hort 38(1): 20-27.

14. Chu CL \& Wilson KR (2000). Evaluating maturity of Mclintash and red delicious apple. Agri and rural division, ministry of Agriculture and food Ontario Canada order, pp 88-117.

15. Steel RGD Torrie JH \& Dickey DA (1997). Principles and procedures of statistics. Abionomial approach $3^{\text {rd }}$ edition. McGraw Hill Companies inc New York USA.

16. Ge LL Tian HQ \& Russell SD (2007). Calcium function and distribution during fertilization in angiosperms. American $J$ Bot 94(6): 1046-1060.

17. Fediala WA, Mosa EG, El-Megreed NAA \& Paszt LS (2015). The effect of the foliar application of Potassium, Calcium, Boron and Humic acid on vegetative growth, fruit set, leaf mineral, yield and fruit quality of 'Anna' Apple trees. American J Exp Agri 8(4): 224-234.

18. Wahab M, Ullah Z, Usman M, Nayab S, Ullah M, Sajid M \& Sohail K (2016). Effect of three ca- Sources application on fruit quality attributes of three peach cultivars in Pakistan. Pure Appl Biol 5(3): 464-470.

19. Feagley SE. \& Fenn LB (1998). Using soluble calcium to stimulate plant growth. Teas Agricultural Extenstion Service Agricultural communication The Texas AM University System L-5212.

20. Johnson RS (2008). Nutrient and water requirments of peach trees. In Lyne D.R. and D. Bassi (ed) The peach Botany Production and Uses $\mathrm{CAB}$ International UK, pp 310-311.

21. Kadir SA (2005). Influnce of pre-harvest calcium application on storage quality of 'Jonathan' apple in Kansas. Transaction of the Kansas Academy of Sci 118: 129-136. 
22. Sarrwy SMA, Gadalla EG \& Mostafa EAM (2012). Effect of calcium nitrate and boric acid sprays on fruit set, yield and fruit quality of CV. Amhat Dateplam. World J Agri Sci 8(5): 506-515.

23. Alakmy HA (2012). Effect of calcium Application and Wrapping treatments on Fruit Quality of early Grande Peach Trees (Prunus Persica L.). J of Appl Sci Res 8(7): 3845-3849.

24. Mahajan BVC \& Sharma RC (2000). Effect of pre-harvest application of growth regulators and calcium chloride on physicchemical characteristics and storage life of peach cv. Shan-e-Punjab, Haryana. J Hort Sci 29(1\&2): 41-43.

25. Rab A \& Haq I (2012). Foliar application of calcium chloride and borax influences plant growth, yield and quality of tomato (Lycopersicon esculentum mill) fruit. Turk J Agric 36: 695-701.

26. Conway WS (1982). Effect of postharvest calcium treatment on decay of "Golden delicious" apples. Plant Disease 66: 402403.

27. Pooviah BW (1988). Molecular and cellular aspects of calcium action in plant. Hort Sci 23(2): 267-271.

28. Khalifa RKH, Omaima M, Hafez M \& Abd- El-Khair H (2009). Influence of foliar spraying with boron and calcium on productivity, fruit quality, nutritional status and controlling of blossom end rot disease of Anna apple trees. World J Agri Sci 5(2): 237-249.

29. Tomola K, Montanes VJ \& Monge L (1998). Effect of calcium sprays on storage quqlity of quality of Sampion apples. Proceedings of the third international symposium on mineral nutrition of deciduous fruit trees. Acta-Horticul 448: 59-65.

30. Tabatbaie SJ \& Malakouti MJ (1998). The effect of calcium chloride on fruit firmness and quality in Red Delicous apple. Soil and Water J 12(1): 43-49.

31. Hayat I, Masud T \& Rathore HA (2003). Effect of coating and wrapping materials on the shelf life of apple (Malus domestica cv. Borkh). Int J of Food Safety 5: 24-34.

32. Jan I, Rab A, Sajid M, Ali A \& Shah ST (2012). Response of apple cultivars to different storage durations. Sarhad J Agric 28(2).

33. Bidabe B (1970). Apple quality in relation to picking and eating time. Aroboric fruit. Aust J Exp Agr 17:26-28.

34. Veschugin SV (2008). Verietal peculiarities of the quality of apple fruit in garden for storage in the Lower Volga. Academic Degree for candidate of Agricultural Sci thesis (Ru).

35. Dzonova M, Petrovska V, Vesova N \& Baurer O (1970). Change in some contituents of apple kept in cold chamber and in refrigerator. Hort Absts 23: 159-68.

36. Tuetal K, Nicolai B \& Baerdemaeker JD (2000). Effect of relative humidity on apple quality under simulated shelf temperature storage. Scientia Hort 85(3): 217-229.

37. Allan BW, Cox KA, White A \& Ferguson IB (2003). Low temperature conditioning treatments reduce external chilling injury of 'Hass' Avocados. Post Bio Tech 28(1): 113-122. 